
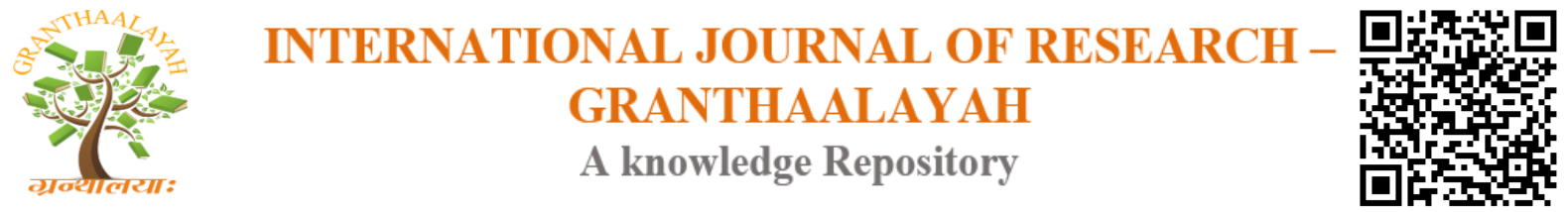

Science

\title{
AN ASSESSMENT OF GROSS BETA RADIOACTIVITY CONCENTRATION IN WELL WATER IN SOME PARTS OF KADUNA SOUTH AND ENVIRONS, NIGERIA
}

\author{
A. A. Kassimu ${ }^{1}$, P. M. Gyuk ${ }^{2}$, B. Ahmadu ${ }^{* 2}$, H. O. Aboh ${ }^{2}$, M. D. Dogara ${ }^{2}$, H. Ali ${ }^{3}$ \\ ${ }^{1}$ Air Force Research and Development Centre, Kaduna \\ ${ }^{2}$ Department of Physics, Kaduna State University, Kaduna \\ ${ }^{3}$ Physics Department, Nigeria Defense Academy, Kaduna
}

\begin{abstract}
Twelve (12) samples of water from hand-dug wells in some parts of Kaduna South and Environs were selected using a stratified random sampling. Twenty (20mils) of concentrated nitric acid were added to each two liters of the sampled water for preservation. The samples were then evaporated and counted for Gross Beta activity using MPC-2000-DP Model Gas free Proportional Counter at Centre for Energy Research and Training (CERT), Ahmadu Bello University, Zaria. Results show that, the range of Beta activity in water in the area was 0.006 to $0.808 \mathrm{~Bq} / \mathrm{L}$, with Geometric mean of $0.120 \pm 0.077 \mathrm{~Bq} / \mathrm{L}$. The overall results show that, the Beta activity have their values below WHO recommended practical screening level of $1.0 \mathrm{~Bq} / \mathrm{L}$ radioactivity for drinking water.
\end{abstract}

Keywords: Gross Beta; Radioactivity; Concentration; Dug-Well; MPC-2000-DP Gas Free Proportional Counter.

Cite This Article: A. A. Kassimu, P. M. Gyuk, B. Ahmadu, H. O. Aboh, M. D. Dogara, and H. Ali. (2017). "AN ASSESSMENT OF GROSS BETA RADIOACTIVITY CONCENTRATION IN WELL WATER IN SOME PARTS OF KADUNA SOUTH AND ENVIRONS, NIGERIA." International Journal of Research - Granthaalayah, 5(10), 129-136. https://doi.org/10.29121/granthaalayah.v5.i10.2017.2290.

\section{Introduction}

Water is fundamental to life here on earth, and, therefore is one of our most valuable resources. The supply of clean, abundant water sources is a major challenge facing modern civilization, and as such, the topic of many research endeavors. The challenge includes the securing of water supplies in the face of climate changes and population growth, and the mitigation of ongoing detrimental effect of modern world. The use of water cuts across industrial, agricultural and domestic uses. The two main sources of water are rain and ground water sources. It is found in rivers, wells, dams, lakes and streams. Human activities and natural phenomenon constantly polluting the sources of water and affect water quality. Water pollution arises as a result of waste 
and sewage disposal into the environment and rivers by industries, hospitals and use of materials such as fertilizers by farmers. On the other hand, individuals also cause ground water contamination by improper disposal of wastes namely motor oil, detergents and cleaners can leak into water sources. These disposed materials often contain radioactive materials (solid, liquid, or gaseous) which contribute significantly to the background activity of the water bodies (Gondar, 2011). Another form of water pollution is as a result of Naturally Occurring Radioactive Materials (NORMS) that emits alpha, beta and gamma radiations. These usually have elements in the uranium and thorium series whose radioactive gaseous daughter (radon and thoron) in particular cause an appreciable airborne particulate activity and contribute to the radioactivity of rain and ground waters. They contaminate the water body directly with their radionuclide products; and indirectly, through the radon and thoron gaseous products which can solidify and attach themselves as aerosols to the air particles and are washed down by rain into water bodies. Furthermore, flowing water encounters shelves, sedimentary rocks, igneous rocks and phosphate rocks all of which are also radioactive (Santchi and Honeyman, 1989). All these contribute to the level of radioactivity in water. The activity concentration of natural radionuclides depends on the water sources. In the surface water, activity concentrations are typically low while drinking water sourced from deep wells and boreholes are usually expected to have higher concentration of radioactive nuclides. This is because they pass through fractures in bedrocks or within the soil which contains minerals deposits that might have radioactive constituents and thus leaking into the water ways. Also the concentration increase in summer due to the high evaporation rates and the increase of the solubility of the salts due to higher temperature of the water (Kehagia et al., 2007). In addition to radioactivity, it has a chemical toxicity that predominantly affects the kidneys (Auvinen et al., 2002; Kurttio et al., 2005). According to Arnold et al. (1992), some radionuclides are chemically similar to some minerals in the human body and so when they are taken into the body, they mimic those minerals in the organs. For instance ${ }^{226} \mathrm{Ra},{ }^{38} \mathrm{Sr}$ and ${ }^{56} \mathrm{Ba}$ (Arnold et al., 1992) are found to have chemical similarity with ${ }^{20} \mathrm{Ca}$ in the bone, when these radionuclides get into the body, they are deposited at the bone marrow, causing damage to bone cells through Osseo Sarcoma (bone cancer). Exposure to radiation is harmful to living tissues because of its ionizing power in matter. This ionization can damage living cells directly, by breaking the chemical bonds of important biological molecules like DNA, or indirectly, by creating chemical radicals from water molecules in the cells, which can chemically attack biological molecules (UNSCEAR, 1993). To some extent, these molecules are repaired by natural biological processes; however, the effectiveness of this repair depends on the extent of damage. Obviously, if the repair is faulty or not made at all, the cell may then suffer either of these possible fates (Cember, 1996): Death of the cell, an impairment in the natural functioning of the cell leading to somatic cell effects, i.e. physical effects suffered by the irradiated individual such as cancer and permanent alteration of the cell which is transmitted to later generations, i.e. a genetic mutation.

Radioactivity in drinking water is an important mode of transfer of radionuclides from environment to man. The most important natural radionuclides in drinking water are tritium, potassium-40, radium, radon and gamma emitters. Therefore, measuring the radioactivity in drinking water is of great interest in environment studies (Ajayi and Owolabi, 2008). A gross alpha test is the first step to determining the level of radioactivity in drinking water. This test serves as a preliminary screening device and determine whether additional is advisable (Ajayi and Owolabi, 2008). Gross alpha is more of concern than gross beta for natural radioactivity in 
water as it refers to the radioactivity of Th, U, Ra as well as Rn and daughters (USEPA, 1997). If the gross alpha and gross beta are less than 0.5 and $1.0 \mathrm{~Bq} / \mathrm{L}$ respectively, it can be assumed that the Total Indicative Dose (TID) is less than the parametric indicator value $0.1 \mathrm{mSv} / \mathrm{year}$ and no further radiological investigation is needed. If the gross alpha activity exceeds $0.5 \mathrm{~Bq} / \mathrm{L}$ or gross beta activity exceeds $1.0 \mathrm{~Bq} / \mathrm{L}$, analysis for specific radionuclides is required (WHO, 1993). Parts of Kaduna south and environs, like many other parts in the country, due to portable water scarcity, people normally collect water from wells and boreholes (deep and shallow). The public water boards are generally ineffective in supplying portable drinking water; therefore most of the populations rely on untreated ground water sources (borehole and well) for domestic and industrial purposes. The ground water collected from dug wells and boreholes samples are not entirely free from radioactive pollutants which are hazardous to human health. Therefore, there is need to determine the concentration of gross alpha and gross beta particles in wells and boreholes water from these areas assess the radiological health risks due to consumption of water from wells water and boreholes sources on the area because communities from all parts of the country and beyond are involved. This research help in understanding a quantitative detection of gross alpha and beta radioactivity which is important for a quick survey of both natural and manmade radioactivity in dug-wells and boreholes water in the study area. Radioactivity in drinking water is one of the major ways in which radionuclides from the environment gets into the human body, which might consequently lead to radiation-induced disorder (USEPA, 2010). There is evidence from both human and animal studies that radiation exposure at lower to moderate doses, may increase the long term incidence of cancer and that the rate of genetic malformations may increase by radiation exposure (Otton, 1994). It is therefore important to determine the amount of radioactivity in drinking water for every area where people reside, so as to guard against its deleterious effects (WHO, 2006).

Some research had been carried out in the field radioactivity in water in different parts of world in the past. A survey had been carried out to determine radioactivity in water sources in Okparecreeks, Delta State (Jibril et al., 1999). He deduced that the alpha and beta activities in the Okpare creek are far below the practical screening level of radioactivity in drinking water of $0.5 \mathrm{~Bq} / \mathrm{L}$ for alpha and $1.0 \mathrm{~Bq} / \mathrm{L}$ for beta recommend by WHO. Onoja (2004) determined gross $\alpha$ and $\beta$ activity in well water from the Zaria area. The result shows a geometric mean value of $75.53 \mathrm{Bqm}^{3}$ (or $0.075 \mathrm{BqL}-1$ ) for $\beta$ activity. Tajudeen (2006) carried out a similar work in the Gwammaja area of Kano Metropolitan City and the result shows a geometric mean value of 0.05 $\mathrm{Bqm}^{3}$ for $\beta$ activity. Habila worked on the survey of gross beta radioactivity in wells and boreholes from Jos city. The result shows that the range of $\beta$ activity varied from 0.25 to 9.64 $\mathrm{Bq} / \mathrm{L}$, with a geometric mean of $1.56 \mathrm{~Bq} / \mathrm{L}$ (Habila, 2008). The aim of this research is to determine the gross alpha and beta radioactivity concentration in the area. This study will also ascertain the safety of drinking water in well water sources from the study area.

\section{The Study Area}

The area under study is some parts of Kaduna South and Environs and this research is limited to dug-wells water source used by people of the region for drinking, domestic activities irrigation and animal husbandry. The area is shown in fig 1.2 below. The area is bounded by latitudes $10^{\circ}$ $25.28^{\prime} \mathrm{N}$ and $10^{\circ} 35.53^{\prime} \mathrm{N}$ and Longitudes $7^{\circ} 21.49^{\prime} \mathrm{E}$ and $7^{0} 30.00^{\prime} \mathrm{E}$. It lies within parts of Kaduna South and Chikun Local Government Areas of Kaduna State. It covers an area of 
approximately $268.36 \mathrm{Km}^{2}$, in the Basement Complex of North Central Nigeria, the area is the Industrial layout and most of the industries are located there suggesting predominantly Industrial activities zone. The study area lies within the Guinea Savannah belt, which experiences the tropical Savannah climate with two distinct seasons. The area has a vast fertile land which is suitable for the cultivation of a wide range of cash and food crops. This condition makes agricultural activities the main backbone of the economy of the people. The major food crops grown in the areas are maize, soya beans, cassava guinea corn, cocoyam and yam are cultivated in the area. The main source of water in the communities is borehole. However, some residents of the communities depend on streams, rivers and wells as their water sources. The above reasons make it imperative for baseline study such as this to establish baseline radioactivity levels which will serve as reference data for future studies.

Twelve water samples were collected from dug-wells within the study area namely: Kudenda, Nassarawa, Gonin Gora, Ungwan Romi, Kakuri, Narayi, Television, Sabon Tasha, Barnawa Ungwan Boro, Kamazou and Mahuta. The samples were collected in 2-litre of plastic containers and were taken to Centre for Energy Research and Training CERT, Ahmadu Bello University, Zaria for analyses.

\section{Materials and Methods}

The materials used for this experiment are as follows, Drying Oven, Drying Lamp, Glass ware, Analytical balance, Electric hot plate, Infrareds, Ceramic dishes, Planchet, Spatula, and weighing balance, Syringe, Desiccator, Beakers and GPS.

The method used for the sampling is stratified random sampling (Williams, 1977). The sampling procedures include the following: The sample container was rinsed three times with the water being collected to minimize contamination from the original content of the sample container, The amount collected was such that an air space of about $1 \%$ of container capacity was created for thermal expansion was left, The water samples were immediately acidified with $20 \mathrm{ml}$ of nitric acid per 2liters of sample collected to reduce $\mathrm{PH}$ and to minimize the absorption of radioactivity into the walls of the containers (ISO, 1992) and the samples were tightly covered and kept in the laboratory for analysis.

For the purpose of analysis, an Acetone (a cleansing agent) was used to wash the equipment needed for the Sample preparation. About $600 \mathrm{~cm}^{3}$ of the sampled water was measured and transferred to a beaker. The sample was evaporated carefully on a Binatone temperature adjustable hot plate. The evaporation was done at the temperature less than $100^{\circ} \mathrm{C}$ for eight hours until the volume was reduced to about $50 \mathrm{ml}$ and allowed to cool. The concentrated solution was transferred to a weighed Planchette. The beaker was carefully washed with a minimum amount of water and the washings transferred to the Planchette. Few drops of Vinyl acetate were added to the solvent to aid even distribution on the Planchette. The sample was heated again to dryness and residue obtained. The Planchette and residue were weighed and by subtraction, the mass $\mathrm{m}$ (mg) of the ignited residue was obtained. The residue was dispersed evenly over the Planchette by slurring with a few drops of ethanol and allowed to dry. The Planchette was weighed again to ensure that no residue has been lost. This procedure was repeated for all the samples. The sample preparation efficiency was derived by taking the weight of the empty Planchette $W_{B}$ and the 
weight of the Planchette plus sample after evaporation to $50 \mathrm{ml}, \mathrm{W}_{\mathrm{B}+\mathrm{S}}$. The difference between $\mathrm{W}_{\mathrm{B}+\mathrm{S}}$ and $\mathrm{W}_{\mathrm{B}}$ gives the weight of the residue. The ratio of the difference between the weights of the residue to $0.0770 \mathrm{~g}$ as specified by ISO multiplied by 100 gives the sample efficiency as shown in equation

$$
\text { Sample efficiency }=\frac{w_{B+s-w_{B}}}{0.077} \times 100 \%
$$

The gross Beta counting equipment used in this work was the MPC-2000-DP low background beta detector. The alpha standard used for this project work is plutonium- 239 sources. It is a sealed calibration source used to determine efficiency in the proportional counter. While the beta standard is strontium-90.The alpha and beta standards were used to calibrate the proportional counter.

The equipment is a non-gas proportional counter with an ultra-thin window. For the gross alpha counting, the desired weight of $0.0770 \mathrm{~g}$ of residue on the Planchette was transferred to the sample carrier of MPC-2000-DP model detector. The carrier was then placed on the sample drawer and closed. Counting was done automatically according to the selected count mode when the appropriate sample information was entered (The detector was operated in beta mode to obtain the count rates of beta in counts per minutes respectively). The activity concentration (C) in Becquerel's per Litre was calculated using the expression

$$
\beta A,(B q / l B q / l)=\frac{\beta \text { count rate }(\mathrm{cpm})-B K G \text { countrate }(\mathrm{cpm})}{\text { sample eff } \mathrm{x} \text { sample size } \mathrm{x} \text { detector eff }} \times 0.0167
$$

\section{Results and Discussion}

The measured concentration values for the twelve well water samples used for the gross beta counting are presented in Table 1 according to their locations. The beta activity concentration in table I was obtained using equation (1.2) above.

Table 1: Result of Gross Beta Radioactivity Concentration obtained

\begin{tabular}{llll}
\hline S/N & $\begin{array}{l}\text { Sample } \\
\text { Location }\end{array}$ & Geographical Location & $\begin{array}{l}\text { Beta } \\
\text { Activity in } \\
\text { Bq/L }\end{array}$ \\
& & & \\
\hline 1 & Kakuri & $10^{\mathrm{O}} 28.3612 \mathrm{~N}, 7^{\mathrm{O}} 25.0102 \mathrm{E}$ & $0.064 \pm 0.083$ \\
2 & Kudenda & $10^{\mathrm{O}} 28.5912 \mathrm{~N}, 7^{\mathrm{O}} 22.0472 \mathrm{E}$ & $0.382 \pm 0.197$ \\
3 & Nassarawa & $10^{0} 28.774^{\prime} \mathrm{N}, 7^{0} 23.749^{\prime} \mathrm{E}$ & $0.808 \pm 0.100$ \\
4 & Ungwan Romi & $10^{0} 26.012^{\prime} \mathrm{N}, 7^{0} 25.778^{\prime} \mathrm{E}$ & $0.093 \pm 0.064$ \\
5 & Television & $10^{0} 26.805^{\prime} \mathrm{N}, 7^{0} 25.567^{\prime} \mathrm{E}$ & $0.283 \pm 0.104$ \\
6 & Narayi & $10^{0} 28.593^{\prime} \mathrm{N}, 7^{0} 27.223^{\prime} \mathrm{E}$ & $0.006 \pm 0.006$ \\
7 & Sabo Tasha & $10^{0} 27.281^{\prime} \mathrm{N}, 7^{0} 26.489^{\prime} \mathrm{E}$ & $0.118 \pm 0.100$ \\
8 & Ungwan Boro & $10^{0} 27.510^{\prime} \mathrm{N}, 7^{0} 27.994^{\prime} \mathrm{E}$ & $0.006 \pm 0.003$ \\
9 & Gonin Gora & $10^{0} 25.925^{\prime} \mathrm{N}, 7^{0} 23.045^{\prime} \mathrm{E}$ & $0.088 \pm 0.083$
\end{tabular}




\begin{tabular}{llll}
10 & Barnawa & $10^{0} 28.583^{\prime} \mathrm{N}, 7^{0} 27.223^{\prime} \mathrm{E}$ & $0.099 \pm 0.042$ \\
11 & Kamazou & $10^{0} 27.603^{\prime} \mathrm{N}, 7^{0} 29.603^{\prime} \mathrm{E}$ & $0.025 \pm 0.039$ \\
12 & Mahuta & $10^{0} 25.652^{\prime} \mathrm{N} 7^{0} 31.712^{\prime} \mathrm{E}$ & $0.300 \pm 0.106$ \\
13 & Mean & & $0.120 \pm 0.077$ \\
14 & Range & & $0.006 \pm 0.808$ \\
\hline
\end{tabular}

\subsection{Discussion}

The gross Beta activity concentrations measured in the study area shows that the wells water samples has gross beta concentration values which ranged from $0.006 \mathrm{~Bq} / \mathrm{L}$ to $0.808 \mathrm{~Bq} / \mathrm{L}$ with a mean value of $0.120 \pm 0.077$.

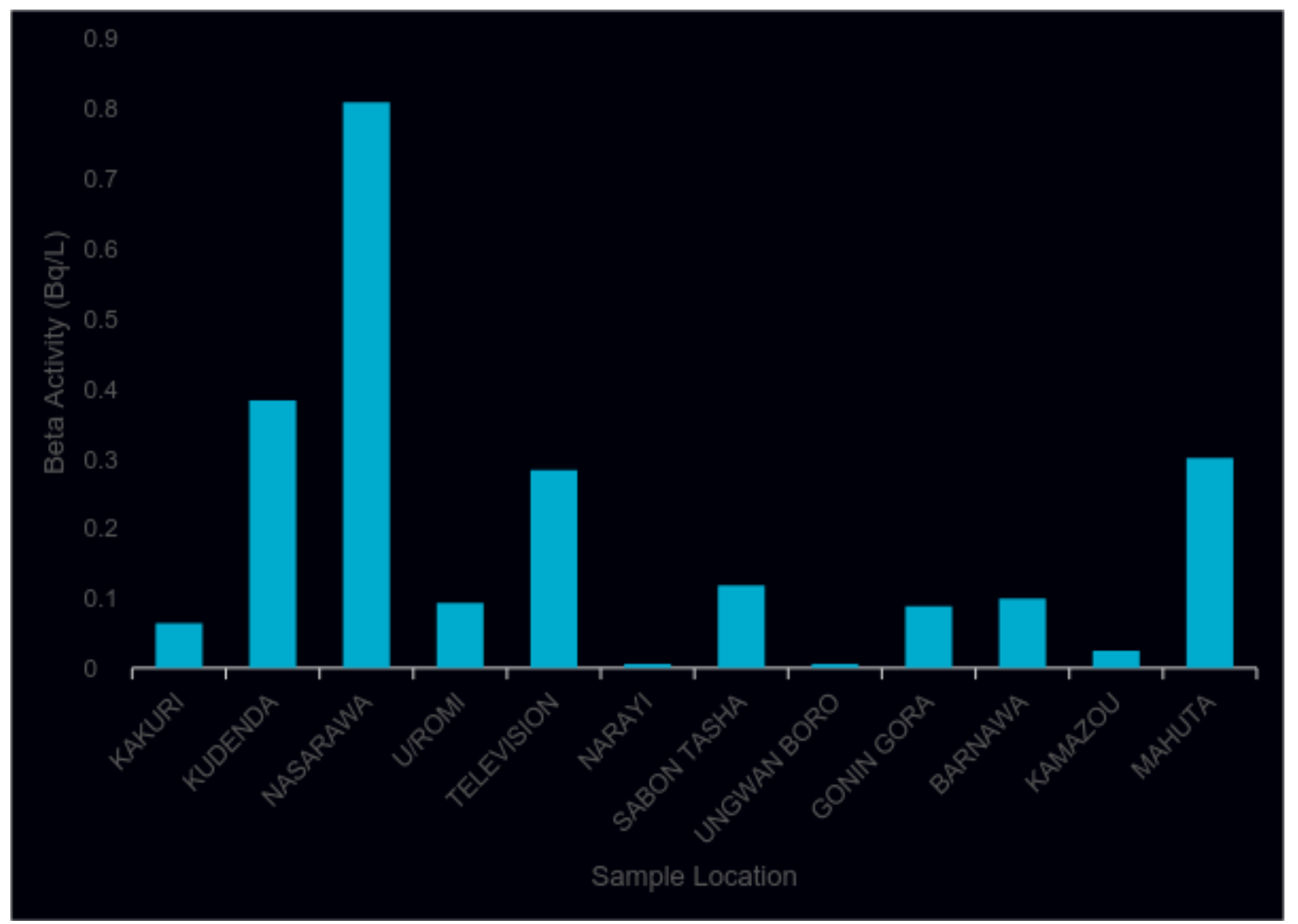

Figure 1: A Bar Chart Plot Showing the Activity concentration in the study area.

Figure 1 above is a bar chart showing the level of beta activity concentration in the study area. The higher value of gross beta activity of $0.0808 \mathrm{~Bq} / \mathrm{L}$ in Nassarawa area could be as a result of presence of industries in the area and also the geological formation of the area whose land is highly invaded with phosphorus, a by-product of phosphate that has potassium- 40 which is a beta and gamma emitter whose source is fertilizer used by farmers. Though the distribution of the gross activity (beta) concentration show that the values significantly vary within the sample area. 


\subsection{Comparison of Result}

Comparing the average value $0.120 \pm 0.077 \mathrm{~Bq} / \mathrm{L}$ of Beta activity obtained in this work with 2.369Bq/L in Nassarawa by Ahmed, 2014; 1.56Bq/L in Jos by Habila (2008). Shows that the gross beta activity in this study area is relatively low. Also, comparing with the average value of $0.07553 \mathrm{~Bq} / \mathrm{L}$ obtained in Zaria by Onoja, (2004); 0.00005Bq/L in Kano by Tajudeen, (2006); shows that the gross beta activity in the study area is relatively high. Thus regular program of environmental audit and monitoring is here by recommended.

\section{Conclusion}

Our assessment and study of gross beta radioactivity concentration indicates that the water sample under investigation has a low concentration of a Beta emitters and the activity was less than $1.0 \mathrm{~Bq} / \mathrm{L}$ limit set by WHO. We conclude that all the radioactivity of water samples are below the limit set by WHO. To the best of our knowledge, this is the first detailed study of gross beta activity concentration in wells water samples in some parts of Kaduna south and Environs. However, more research has to be done in order to identify the individual radionuclides contributing to the total gross radioactivity. This is a matter of further research work.Long term measurements are essential to give a conclusive picture of the radioactivity of water obtained from the wells that serve the people, in other to avert any serious health effects.

\section{References}

[1] Ajayi O. S Owolabi TP (2008) Determination of natural radioactivity in drinking water in private dug wells in Akure, Southwestern Nigeria. Radiat Protect Dosim. 128:477-484

[2] Avwiri G. O. (2002). Determination of Radionuclide Levels in Soil and Water around Cement Companies in Port Harcourt. J. appl. Sci. Envir. Mgmt 9 (3), 27-29.

[3] Cember, H. (1996). Introduction to health Physics, 3rd Edition. McGraw Hill, mc, Toronto pp. 220-231.

[4] Gondar, G. (2011). Pollution. Available at:http://www.sambal.co.uk/pollution.

[5] Habila, N. (2008). Survey of Gross Alpha and Beta Radioactivity in Jos City. Unpublished M.Sc. thesis, University of Jos, Nigeria.

[6] ISO (1992). Water Quality Measurement of Gross Alpha Activity in Non-saline Sater. International Standard Organization, (ISO 9696). Pp8

[7] Jubril N. N., Mabawonku A. O., Oridate A. A and Ujiagbedion A. J. (1999). Natural Radionuclide Concentration Levels in Soil and Water around a Cement Factory at Ewekoro, Ogun, Nigeria. Niger.J. Phys. 11: 12-16.

[8] Kehagia, K., Koukouliou, V., Bratakos, S., Potiriadis, K. (2007). Biossay measurements for the evaluation of occupational exposure during the decontamination of a phosphoric production unit in Greece In: Proceedings of the 9th International Conference on Health Effects of Incorporated Radionuclides.

[9] Kurttio, P., Salonen, L., Taina, I., Pekkanen, J., Pukkala, E., \& Auvinen, A. (2006). Well water radioactivity and risk of cancer of the urinary organ. Environmental Research, 102, 333-338

[10] Onoja, R. A. (2004). Survey of Gross Alpha and Beta Radioactivity in Well Water from Zaria

[11] Otton, J. K. (1994). National Radioactivity in the Environment [Online] Available at:http://energy.usgs.gov/factsheets/radioactivitity.

[12] Sajo Bohus, L., Gomez, J., Capote, T., Greaves, E. D., Herrera, O., Salazar, V. and Smith, A. (1997). Gross Alpha radioactivity of Drinking Water in Venezuela. J. Environ Radioactivity 3: $305-312$. 
[13] Santschi, P.H. and Honeyman, B.D. (1989). Radionuclides in Aquatic Environment Radiat. Phys. Chem. 34::2 16-219

[14] Tajudeen, H.V. (2006). Survey of Radioactivity in Wells and Bore holes from Gwammaja Area of Kano City. Unpublished M.Sc. thesis, Ahmadu Bello University, Zaria.

[15] [15] UNSCEAR (1993). Sources and biological effects. United Nations Scientific Committee on the Effects of Atomic Radiation Report to the General Assembly, with annexes. UN sales publications; New York.

[16] United State Environmental Protection Agency (USEPA), (1997). Prescribed Procedures for Measurement of Radioactivity in Drinking Water. Environmental Monitoring and Support Laboratory. EPA 600/4-80-032.

[17] United State Environmental Protection Agency (USEPA), (2010). Drinking Water Contaminants United State Environmental Protection Agency, pp.15.

[18] WHO. (2003). Guidelines for Drinking Water Quality. 3rd ed., World Health Organization, Geneva, Switzerland.

[19] WHO. (2004). Guidelines for Drinking Water Quality, 3rd Edition p37-44

[20] WHO. (2006). Guidelines for drinking-water quality, 3rd editionn, Geneva. (Vol. 1, pp. 197-207)

[21] WHO (2008). Guideline for Drinking Water. 3rd Edition, incorporating the first and second Addendum, Vol.1.Recommendations. Geneva.

[22] Williams, G. C. (1977). Sampling Techniques. 3rd Edition. New York pp.89-92.

\footnotetext{
*Corresponding author.

E-mail address: bitahmed77 @gmail.com
} 